\title{
33. LOWER OLIGOCENE THROUGH PLEISTOCENE PLANKTONIC FORAMINIFERAL BIOSTRATIGRAPHY, NORTH ATLANTIC SITES 558 AND 563 (MID-ATLANTIC RIDGE) ${ }^{1}$
}

\author{
Dorothy J. Echols, Department of Earth and Planetary Sciences, Washington University ${ }^{2}$
}

\begin{abstract}
A preliminary biostratigraphic zonation of Site 558 (Holes 558 and 558A), lower Oligocene through Pleistocene, and Site 563, lower Oligocene through upper-middle Miocene, drilled on the west flank of the Mid-Atlantic Ridge is discussed. At Site 558 two holes were drilled by a combination of piston and rotary coring through a stratigraphic sequence from Oligocene through Pleistocene. Except for a gap of approximately $26 \mathrm{~m}$ in the upper-middle Miocene where Holes 558 and 558A do not overlap, the Cenozoic section recovered is the most complete and best preserved stratigraphic succession from this part of the Atlantic.

At Site 563 one hole was drilled. Sediments were washed down to $156.5 \mathrm{~m}$ and then rotary cored to basement . The lower Oligocene through upper-middle Miocene sediments recovered are similar to those drilled at Site 558 both in lithology and fauna.

The biostratigraphic succession at both sites is relatively undisturbed; no major gaps or reworking were noted and sedimentation accumulation rates are similar.

Notably Bolboforma, a tiny spherical calcareous incertae sedis (algae?), was recovered at both sites at the same stratigraphic horizon in the Miocene. This form may have potential as a regional marker in deep-sea sediments.
\end{abstract}

\section{INTRODUCTION}

Sites 556 through 564 (ten holes) were drilled during Leg 82 in an area on the west flank of the Mid-Atlantic Ridge and southwest of the Azores Platform (Fig. 1). The primary objectives of drilling in this area were to sample ocean crust in order to study mantle heterogeneity. The paleontologic objectives were to confirm basement ages and to recover a complete section of Cenozoic pelagic sediments from this part of the Atlantic and, if possible, establish a biostratigraphic zonation and reference section.

The biostratigraphic objectives were achieved; a nearly complete section of the lower Oligocene through Pleistocene was recovered through a combination of hydraulic piston coring and rotary coring in two holes at Site 558 (Fig. 2).

Before this cruise, study of the sedimentation, stratigraphy, paleoenvironment, and geologic history of the area between $20-40^{\circ} \mathrm{N}$ in the mid-Atlantic was limited and based on spot cores and partial sections. On Leg 2 (Blow, 1970), spot cores of the Cretaceous to Pleistocene were taken at Sites 10 and 11. On Leg 37 (Miles, 1977), Sites 334, upper Miocene calcareous pelagic ooze and chalk were cored and, at Site 335, spot cores were taken through $450 \mathrm{~m}$ of Pleistocene through middle Miocene sediments. On Leg 49 (Poore, 1978), at Sites 411, 412, and 413, only Quaternary sediments were recovered (no coring was done at Site 414).

In order to fill the gap in sampling and to provide data for study of the Cenozoic history and paleoenvironment of the area, it was decided that continuous coring

\footnotetext{
${ }^{1}$ Bougault, H., Cande, S. C., et al., Init. Repts. DSDP, 82: Washington (U.S. Govt. Printing Office)

2 Present address: Curtis and Echols, Geological Consultants, 800 Anderson, Houston, Texas 77401 .
}

should be done at as many sites as possible during Leg 82.

Of the nine sites drilled, Sites 558 and 563 , located close to Anomaly 13, were chosen for continuous coring. Sediments recovered at these sites are lower Oligocene to Pleistocene and indicate that during this interval the sites were above the calcite compensation depth (CCD).

Site 558 is located at $37^{\circ} 46.2^{\prime} \mathrm{N}$ latitude and $37^{\circ}$ $20.61^{\prime} \mathrm{W}$ longitude near the Pico Fracture Zone between Anomalies 13 and 15 on the flank of a basement high in water depth of $3754 \mathrm{~m}$. Holes 558 and 558A were drilled at this site. Hole 558 was washed down to a depth of 158 $\mathrm{m}$ and sediments were continuously cored to a total penetration above basement of $408 \mathrm{~m}$. After the first hole was successfully logged, Hole 558A was piston cored to a depth of $132 \mathrm{~m}$, when mechanical problems in the inner core barrel forced termination before biostratigraphic overlap was accomplished. This gap of $26.5 \mathrm{~m}$ represents approximately 2 to $4 \mathrm{Ma}$ of sedimentation (See Fig. 2 which shows the cored intervals, the foraminiferal planktonic zonation of the two holes, and the biostratigraphic gap at Site 558. It also shows for comparison the cored interval and zonation of Hole 563).

At Site 563 (latitude $33^{\circ} 38.53^{\prime} \mathrm{N}$; longitude $43^{\circ}$ $46.04^{\prime} \mathrm{W}$; water depth, $3786 \mathrm{~m}$ ), one hole was drilled on Anomaly 13 on the west flank of the Mid-Atlantic Ridge about 60 miles south of the Hayes Fracture Zone (Fig. 1). Sediments were washed down to $156.5 \mathrm{~m}$ and then 22 rotary sediment cores were taken to basement at $364 \mathrm{~m}$. Sediment for the study of foraminifers was not obtained from Core 563-23, which reached basement.

The hydraulic piston coring program scheduled for this site to retrieve the younger section from $0-156.5 \mathrm{~m}$ had to be cancelled when the bit and core barrel were lost in the hole during the cutting of the third basalt core. 


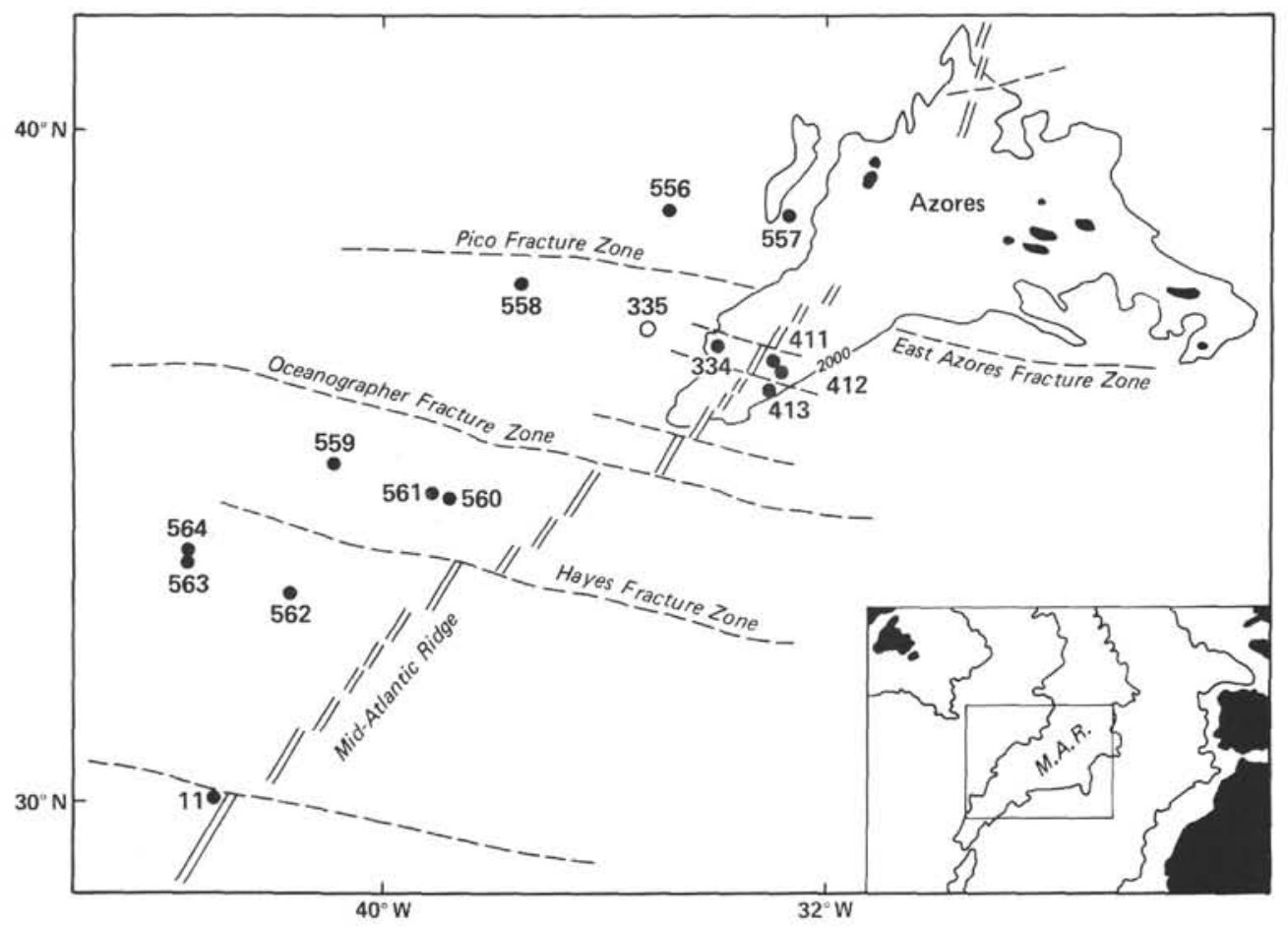

Figure 1. Location of Leg 82 sites and previously drilled Sites 11, 334, 335, 411, 412, and 413.

The sediments recovered at this site are lower Oligocene to late Miocene. The entire section comprises calcareous pelagic ooze. Two sediment units similar to Site 558 can be recognized and their boundary occurs roughly at the same age as Site 558 (Fig. 2).

The purpose of this chapter is to present a preliminary biostratigraphic zonation of the cores recovered at this two sites. At all other sites drilled on Leg 82, holes were washed down and only an occasional rotary core was taken. Brief descriptions of these holes are given in the site reports under Sedimentology and Biostratigraphy (this volume).

Figure 7 in the Explanatory Notes chapter (this volume) shows the biostratigraphic zonation used for all site chapters. The nannofossil and foraminiferal zonation are placed within a numerical time scale correlated with magnetostratigraphy and European stages.

\section{BIOSTRATIGRAPHY}

The planktonic foraminiferal zonation incorporates schemes developed by Bolli (1957); Blow (1969); Berggren (1972, 1978); Berggren and Amdurer (1973); Berggren and Van Couvering $(1974,1978)$; Hardenbol and Berggren (1978); Poore (1978); Postuma (1971); Salvatorini and Cita (1979); Stainforth et al. (1975); and Stainforth and Lamb (1981). Appendix A lists the cores from Holes 558A and 558 and Appendix B lists the cores from Holes 563 allotted for foraminiferal studies. Sample intervals in centimeters, depth below sea floor in meters, meters recovered, age, and planktonic zones are tabulated.

Figure 3 shows a plot of the distribution of selected planktonic foraminifers in Holes 558 and 558A. For com- parison, Table 1 shows significant events in Holes 558 and 563.

The biozones recorded from Hole 558, Core 558-1 through 558-27-2 (158-406.95 m); Hole 558A, Core 558A1 through 558A-16-6 (0-130.13 m); and Hole 563, Core 563-1 through 563-22-4 (156.50-360.04 m) are briefly discussed here from bottom to top.

\section{Oligocene (basement)}

Basalt was reached in 558-27-2 (408 m) and 563-23-3 $(364 \mathrm{~m})$. Washed residues of the last sediment retrieved in 558-27-2 (approximately $406 \mathrm{~m}$ ) contains dolomite rhombs, rare fragments of foraminiferal shells, manganese nodules, and a few fish teeth. A small piece of limestone at the top of Core 563-23 was the last sediment retrieved from that hole.

At these sites, immediately after the formation of new ocean crust (early Oligocene), open ocean pelagic sedimentation began; it continues at present. The Oligocene zonal scheme (Fig. 4) is modified from Stainforth and Lamb (1981).

\section{Pseudohastigerina micra Zone (P18)}

Lower Oligocene sediments recovered at Cores 55826 and 558-25, and Sections 563-22-5 through 563-22-7 contain abundant $P$. micra, a fair number of Chiloguembelina, and typical lower Oligocene globigerinids: Globigerina venezuelana, G. tripartita, G. ampliapertura, G. angiporoides, and $G$. praebulloides. The foraminifers show considerable fragmentation and/or dissolution because of proximity to underlying basalt. Dolomite crystals are abundant and the rhombs can be seen growing in and on the tests (Plate 1, Figs. 1-3). 


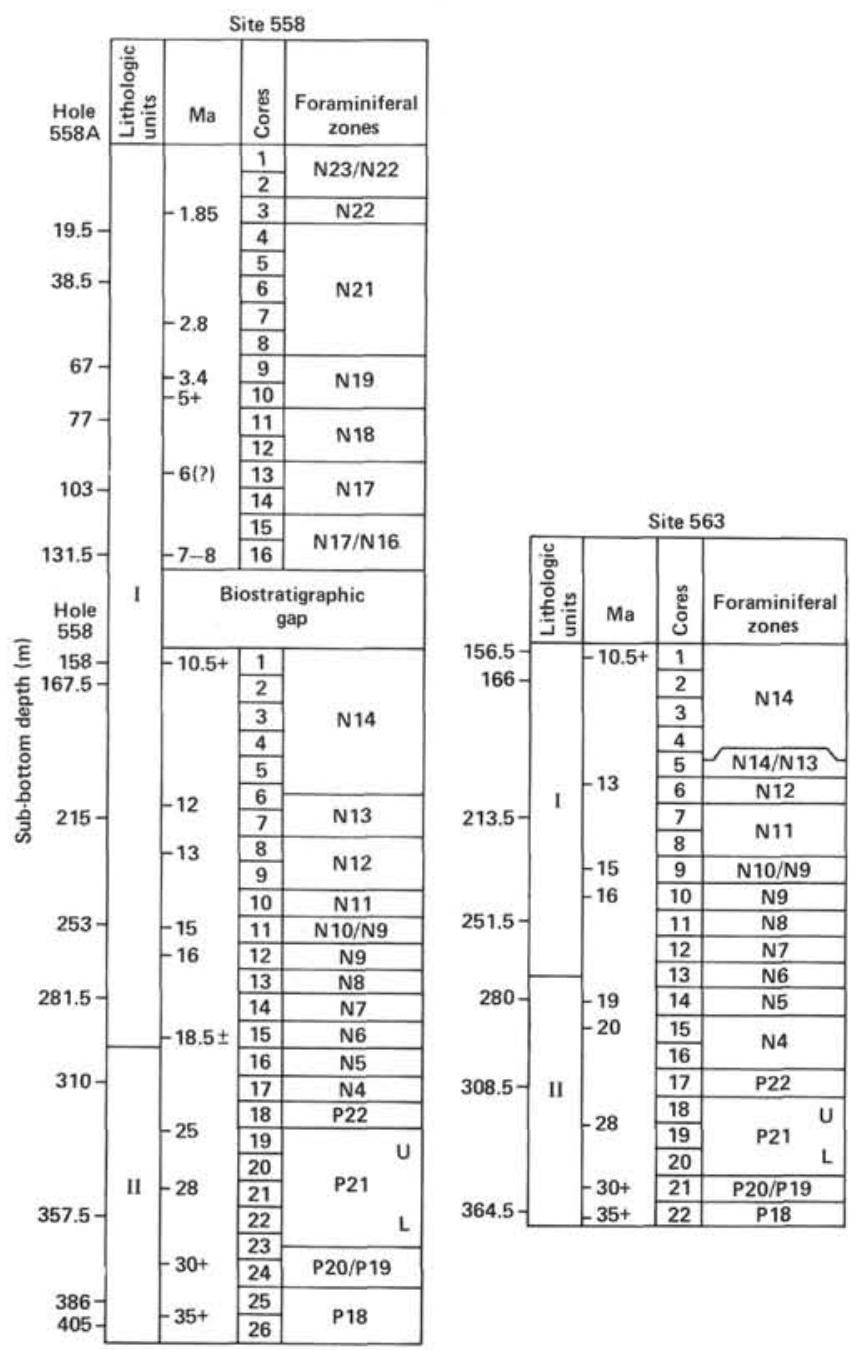

Figure 2. Planktonic foraminiferal zonation at Sites 558 (Holes 558 and 558A) and 563 (Hole 563) showing biostratigraphic gap and the two lithologic units recognized at the sites.

\section{Globigerina ampliapertura Zone (P20/P19)}

Cores 558-24 and 563-21 are assigned to the G. ampliapertura zone. This zone is defined as the interval from the first evolutionary appearance of $G$. selli to the level of the first occurrence of G. angulisuturalis (Blow, 1969; Postuma, 1971; Blow, 1979, Stainforth and Lamb, 1981). The extinction of $G$. ampliapertura occurs shortly after this horizon (Blow, 1969; Stainforth et al., 1975; Stainforth and Lamb, 1981).

The samples studied here are characterized by abundant tiny globigerinids, Chiloguembelina, and a continuation of the fauna found in the older sediments, but Pseudohastigerina micra becomes extinct. The foraminifers still reflect some destruction because of dissolution and dolomite recrystallization.

\section{Globorotalia opima opima Zone (P21)}

Cores 558-23, 558-22, 563-20, and 563-19 are assigned to the lower part of the G. opima opima zone. This entire zone has been defined by the first appearance of Globigerina angulisuturalis (Blow, 1969; Stainforth and
Lamb, 1981; Beckmann et al., 1981) and by the extinction of the nominate subspecies at the upper boundary (Blow, 1969). A secondary datum may be the extinction of Chiloguembelina cubensis that occurs in the middle part of the zone and may mark the lower-upper Oligocene boundary. It has been suggested that because of the abrupt extinction of this species within the G. opima opima zone, this interval could be subdivided (Berggren and Amdurer, 1973) into a lower P21a unit and an upper P21b unit, designating the lower part the $C$. cubensis zone. In the present study the datum is readily recognized. The last occurrence of $C$. cubensis is in Sections 558-22-1 and 563-19-1, which marks the subzone boundary and the boundary between the lower and upper Oligocene.

Samples 558-21 through 558-19 and 563-18 are assigned to the upper part (P21b) of the G. opima opima zone. These samples contain, in addition to abundant tiny globigerinitas, very large forms such as Catapsydrax, Globigerina tripartita, G. venezuelana, and G. gortanii.

\section{Globigerina ciperoensis Zone (P22)}

Cores 558-18 and 563-17 are assigned to the G. ciperoensis zone. The base of this upper Oligocene zone is defined as the level of extinction of Globorotalia opima opima (Blow, 1969; Stainforth et al., 1975). The uppermost boundary and the corresponding base of the next younger (N4) zone is in some dispute. This limit has been defined variously on the first evolutionary appearance of Globigerinoides primordius (= Globigerinoides datum) (Blow, 1969), the level at which various species of Globigerinoides start to diversify (Stainforth et al., 1975; Beckmann et al., 1981), and the first appearance of Globorotalia kugleri (Bolli, 1957, 1966; Postuma, 1971; Stainforth and Lamb, 1981). Much of the confusion in determining the uppermost limits of this zone has been the result of attempts to use the Globigerinoides datum to define the Oligocene/Miocene (Paleogene/Neogene) boundary, a datum shown to be unreliable in many instances (Lamb and Stainforth, 1976; Stainforth and Lamb, 1981; Becker 1982, Srinivasen and Kennett, 1983). The first appearance of various forms of the genus Globigerinoides vary considerably in the geologic record depending upon environmental conditions (Lamb and Stainforth, 1976; Stainforth and Lamb, 1981). In some instances species of $G$. trilobus and $G$. immaturus are known to occur near the base of the Globigerina ciperoensis zone on the Atlantic continental slope, Florida Shelf, and in the Gulf of Mexico (Lamb and Stainforth, 1976; Stainforth and Lamb, 1981; Becker, 1982). Other evidence from around the world (Jenkins, 1960; Caralp et al., 1965; Srinivasen and Kennett, 1983) indicate that this depressed occurrence is not a local phenomenon. It therefore seems appropriate to revert to Bolli (1957; 1966) and his original recommendation and define the top of the Globigerina ciperoensis zone by the first appearance of Globorotalia kugleri (see Fig. 4). Species found within this zone include Globigerina ciperoensis, G. tripartita, G. venezuelana, G. praebulloides, G. angulisuturalis, and Globorotalia siakensis. 


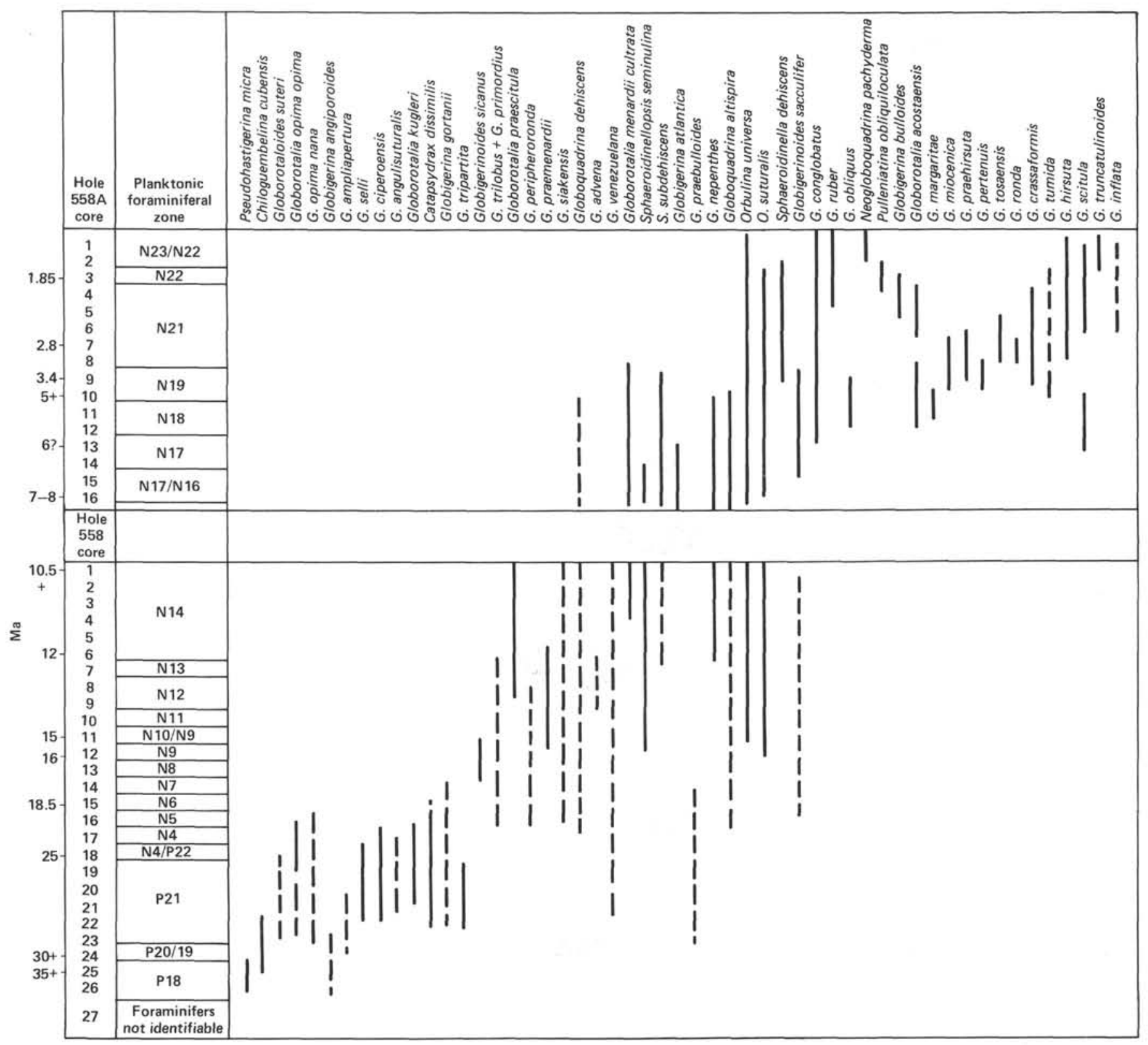

Figure 3. Range of selected Oligocene through Pleistocene planktonic foraminifers; Site 558, Holes 558 and 558A.

\section{Oligocene/Miocene}

\section{Globorotalia kugleri Zone (N4)}

In the framework we are using, $\mathrm{N} 4$ (the G. kugleri zone) straddles the Oligocene/Miocene boundary (see Fig. 4). Cores 558-17, 563-16, and 563-15 are assigned to this interval. The zone is described as the range of G. kugleri from its first appearance at the base (Stainforth and Lamb, 1981) to its disappearance in the lowermost Miocene (Bolli, 1957; 1966; Stainforth et al., 1975; Stainforth and Lamb, 1981).

Srinivasen and Kennett $(1981 ; 1983)$ subdivided zone N4 into lower N4A and upper N4B units using the first evolutionary appearance of Globoquadrina dehiscens (a dissolution-resistant form of wide latitudinal range) as the base of N4B, which they also consider to coincide with the Oligocene/Miocene boundary. Their definition of the two subzones of N4 are as follows:

1. Zone N4A Globigerinoides primordius/Globorotalia kugleri, concurrent range zone of Blow (1969). An uppermost Oligocene assignment is given to the interval from the first evolutionary appearance of Globigerinoides primordius to the first evolutionary appearance of Globoquadrina dehiscens.

2. Zone N4B Globoquadrina dehiscens/Globorotalia kugleri, concurrent range zone proposed. A lower Miocene assignment is given to the interval from the first evolutionary appearance of Globoquadrina dehiscens to the last appearance of Globorotalia kugleri.

The base of N4B, therefore, marks the Oligocene/ Miocene boundary. 
Table 1. First appearance datum (FAD) and last appearance datum (LAD) of a few significant species, Holes 558 and 563 .

\begin{tabular}{|c|c|c|c|c|c|c|c|}
\hline $\begin{array}{l}\text { Hole } 558 \\
\text { Core }\end{array}$ & $\begin{array}{l}\text { Boundaries } \\
\text { FAD/LAD }\end{array}$ & $\begin{array}{l}\text { Sub-bottom } \\
\text { depth }(\mathrm{m})\end{array}$ & $\mathrm{Ma}$ & $\begin{array}{l}\text { Hole } 563 \\
\text { Core }\end{array}$ & $\begin{array}{l}\text { Boundaries } \\
\text { FAD/LAD }\end{array}$ & $\begin{array}{l}\text { Sub-bottom } \\
\text { depth }(\mathrm{m})\end{array}$ & $\mathrm{Ma}$ \\
\hline 1 & & & & 1 & & & \\
\hline 2 & & & & 2 & & & \\
\hline 3 & & & & 3 & & & \\
\hline 4 & & & & 4 & & & \\
\hline 5 & & 196.00 & & 5 & FAD $G$. nepenthes & 194.50 & \\
\hline 6 & FAD Globigerina nepenthes & 205.50 & & 6 & $\begin{array}{l}\text { LAD G. peripher- } \\
\text { oronda }\end{array}$ & 204.00 & \\
\hline 7 & $\begin{array}{l}\text { FAD Sphaeroidinellopsis } \\
\text { subdehiscens }\end{array}$ & & $12-13$ & 7 & & 213.50 & \\
\hline 8 & $\begin{array}{l}\text { LAD Globorotalia periph- } \\
\text { eroronda }\end{array}$ & & & 8 & & & \\
\hline 9 & & 234.00 & & 9 & & & \\
\hline 10 & & 243.50 & & 10 & Orbulina & 242.00 & $15-16$ \\
\hline 11 & & & & 11 & & & \\
\hline 12 & Orbulina & 262.50 & $15-16$ & 12 & FAD G. sicanus & & \\
\hline 13 & & & & 13 & LAD $C$. dissimilis & 270.50 & $18+$ \\
\hline 14 & $\begin{array}{l}\text { FAD Globigerinoides } \\
\text { sicanus }\end{array}$ & & & 14 & & & \\
\hline 15 & $\begin{array}{l}\text { LAD Catapsydrax dissimi- } \\
\text { lis }\end{array}$ & 291.00 & $18+$ & 15 & & & $22-25$ \\
\hline 16 & & & $22-25$ & 16 & FAD G. dehiscens & & \\
\hline 17 & $\begin{array}{l}\text { FAD Globoquadrina } \\
\text { dehiscens }\end{array}$ & & & 17 & & & \\
\hline 18 & & & & 18 & & & \\
\hline 19 & & & & 19 & LAD C. cubensis & 327.50 & $28-30$ \\
\hline 20 & & & & 20 & & & \\
\hline 21 & & & & 21 & LAD $P$ micra & 346.50 & $30+$ \\
\hline 22 & $\begin{array}{l}\text { LAC Chiloguembelina } \\
\text { cubensis }\end{array}$ & 357.50 & $28-30$ & 22 & & & \\
\hline 23 & & & & & & & \\
\hline 24 & $\begin{array}{l}\text { LAD Pseudohastigerina } \\
\quad \text { micra }\end{array}$ & & $30+$ & & & & \\
\hline 25 & & & & & & & \\
\hline 26 & & & $35+$ & & & & \\
\hline
\end{tabular}

The first appearance of Globoquadrina dehiscens as an important planktonic event and a valuable datum for placement of the Oligocene/Miocene boundary was previously recognized by Jenkins $(1965 ; 1971)$ who used it in New Zealand sequences as the base of the Miocene and by Berggren and Amdurer (1973) who used it in North Atlantic sequences as approximating the Oligocene/Miocene boundary. In lower Miocene sections in the equatorial Pacific, Keller $(1980$; 1981a, b) recognized the evolutionary first appearance of $G$. dehiscens as an isochronous event occurring at about $22.2 \mathrm{Ma}$, which is later than the first appearance of Globigerinoides.

In the present study, Globoquadrina dehiscens makes its first appearance in Samples 558-17 and 563-16. Within the Globorotalia kugleri N4 Zone, diminutive globigerinids become a predominant element of the fauna, and Globoquadrina altispira and Globigerinoides primordius makes their first appearances.

\section{Miocene}

\section{Globoquadrina dehiscens Zone (N5)}

The base of this zone is placed at the level of extinction of Globorotalia kugleri and the top is defined by the first appearance of Globigerinatella insueta (Blow, 1969). Cores 558-16 and 563-14 are assigned to this interval. These samples are characterized by abundant planktonic species and large and diverse benthic species; the fauna comprises abundant large and small globigeri- nids, abundant Globigerinoides, Globoquadrina, and Catapsydrax.

\section{Globigerinatella insueta/Catapsydrax dissimilis Zone (N6)}

The base of this zone is placed at the first appearance of $G$. insueta and the top defined by the extinction level of C. dissimilis. Cores 558-15 and 563-13 may belong in this interval.

\section{Globigerinatella insueta-Globigerinoides quadrilobatus trilobus Zone (N7)}

The base of the zone is placed at the horizon immediately above the extinction of Catapsydrax dissimilis and the upper boundary at the first appearance of Globigerinoides sicanus. Although tentative at this time, Cores 558-14 and 563-12 are assigned to this interval. The fauna is characterized by very abundant Globoquadrina dehiscens, very large globigerinids, and absence of $C$. dissimilis.

\section{Globigerinoides sicanus-Globigerinatella insueta Zone (N8)}

The base of N8 is marked by the first evolutionary appearance of Globigerinoides sicanus and the upper boundary by the first appearance of Orbulina suturalis (Orbulina datum). Cores 558-13 and 563-11 are assigned to this zone. The planktonic fauna is common but somewhat fragmented, preservation is moderate. Conspicu- 


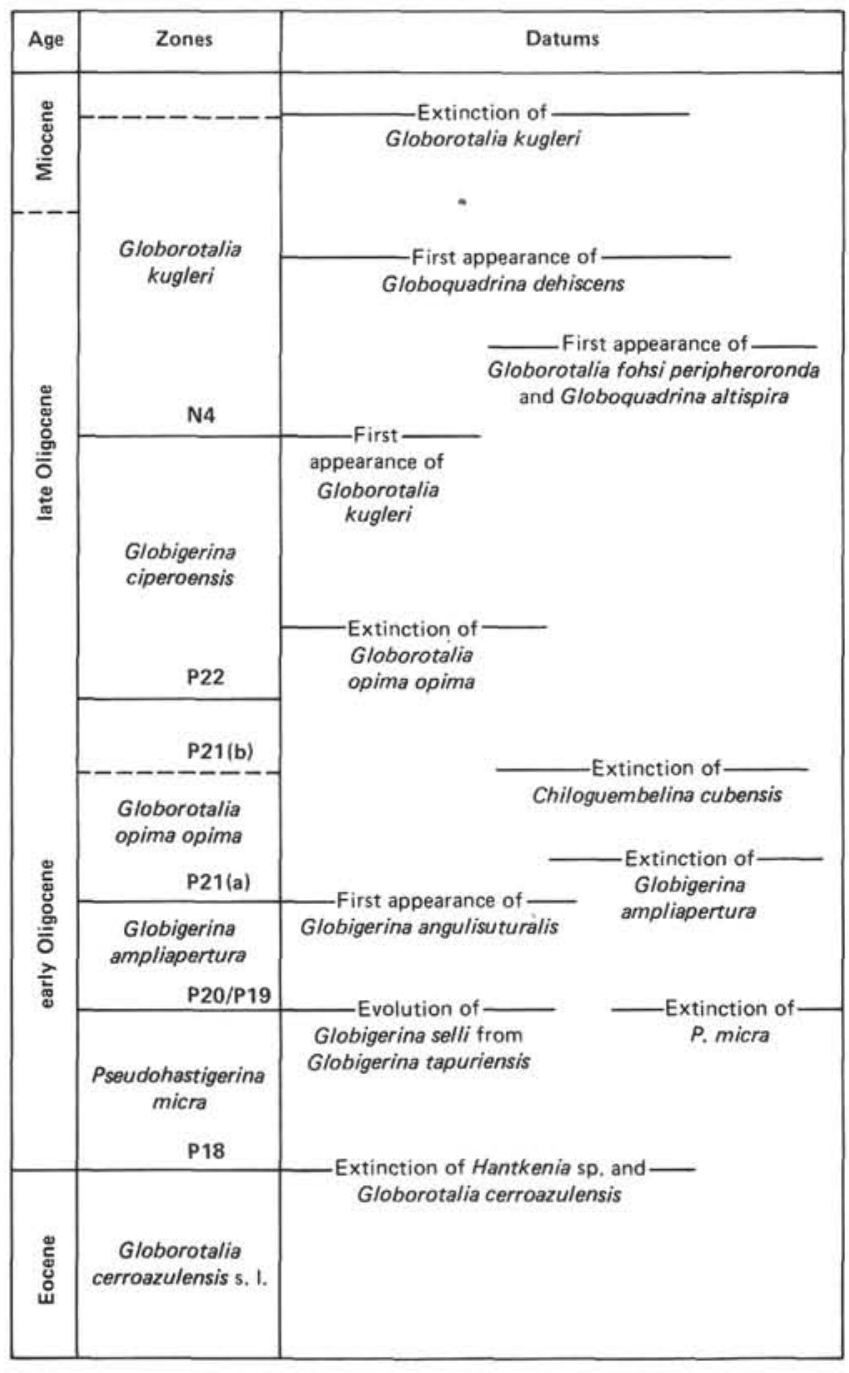

Figure 4. Oligocene zonation modified from Stainforth and Lamb (1981).

ous elements are G. sicanus., G. trilobus, Globoquadrina dehiscens, Globorotalia scitula, and Sphaeroidinellopsis seminulina. The siliceous element (i.e., radiolarians and sponge spicules) is quite common.

\section{Orbulina suturalis-Globorotalia peripheroronda Zone (N9)}

The first appearance of Orbulina suturalis coincides with the lower boundary of this zone and the upper boundary with the first appearance of $G$. peripheroacu$t a$. The top of Zone N9 virtually coincides with the first appearance and evolution of $G$. praemenardii praemenardii from its ancestor $G$. praemenardii archeomenardii. Orbulina first appears in Samples 558-12,CC and 563-10, CC, marking the base of the zone at approximately 266 and $247 \mathrm{~m}$, respectively. The fauna is characterized by abundant but somewhat fractured planktonics.

\section{Globorotalia peripheroacuta Zone (N10)}

The base of this zone is placed at the horizon of the first evolutionary appearance of $G$. peripheroacuta (evolving from its ancestor $G$. peripheroronda) and the upper boundary at the first appearance of $G$. praefohsi. Cores 558-11 and 563-9 may belong within this zone, but at the present time the zone has not been positively identified in the section studied. These cores are therefore tentatively referred to $\mathrm{N} 9 / \mathrm{N} 10$.

\section{Globorotalia praefohsi Zone (N11)}

This middle Miocene zone is defined at the base by the first appearance of $G$. praefohsi (evolving from its ancestor $G$. peripheroacuta) and at the top by the first appearance of $G$. fohsi.

In temperate regions large carinate end forms of the $G$. fohsi lineage are frequently not well developed, and at the sites discussed here this seems to be the case. There is also some evidence that the local distribution of the G. fohsi series is subject to ecologic control. Within the interval, a highly evolved form of $G$. praemenardii with limbated spiral and intracameral sutures in the penultimate whorl is recorded (Salvatorini and Cita, 1979).

Cores 558-10, 563-8, and 563-7 are tentatively assigned to N11.

\section{Globorotalia fohsi Zone (N12)}

The first appearance of $G$. fohsi s.s. defines the base of this zone and the first occurrence of Sphaeroidinellopsis subdehiscens marks the upper boundary. The interval is characterized by G. siakensis, G. praemenardii, G. peripheroronda, G. praescitula, Orbulina universa, and $O$. suturalis. Cores 558-9, 558-8, and 563-6 may be assigned to this zone. Although the $G$. fohsi lineage is not well developed in the area, G. peripheroronda is fairly common. The last occurrence of this form was recognized in samples within the N12 Zone.

\section{Sphaeroidinellopsis subdehiscens-Globigerina druryi Zone (N13)}

This zone is defined at the base by the first appearance of S. subdehiscens, and the upper limit or top of zone is defined by the first appearance of Globigerina nepenthes. Core 558-7 belongs in this interval.

\section{Globigerina nepenthes-Globorotalia siakensis Zone (N14)}

This zone is recognized by the first appearance of Globigerina nepenthes at the base and by the last appearance of Globorotalia siakensis at the upper boundary. The zone is therefore characterized by the concurrence of Globigerina nepenthes and Globorotalia siakensis. The first occurrence of Globigerina nepenthes (or the boundary of N13/N4) was recognized in Samples 558$6, \mathrm{CC}$ and $563-5, \mathrm{CC}$. In these samples, a few typically well developed specimens are present. These cores are assigned to Zones N13/N14. Cores 558-6 (215-205.5 m) and 563-5 $(204-195 \mathrm{~m})$ are particularly interesting because they contain the calcareous (algae?) Bolboforma (Echols, this volume) that seems to be restricted to this short interval. These spherical to flattened spherical calcareous bodies found in the fine fractions have tiny apertures at the end of neck-like projections and are ornamented with spiral ridges and/or spines. They are referred to the incertae sedis (algae?) Bolboforma and de- 
scribed as cysts or reproductive bodies of an (as yet unknown) Miocene algae. They may be regional markers and possibly climatic indicators in deep-sea sediments.

Core 558-5 to Sample 558-1-1, 37-40 cm approximately 205-158 m sub-bottom) and Core 563-4 to Sample 563-1-1, 62-64 cm (approximately 195-157 m subbottom) are considered characteristic of Zone N14. The fauna includes abundant Globorotalia menardii complex, Globigerina nepenthes, common Sphaeroidinellopsis seminulina and S. subdehiscens, Globoquadrina dehiscens, G. altispira, and Orbulina.

\section{Globorotalia acostaensis-G. merotumida Zone (N16)}

The base of this zone defined by the first appearance of $G$. acostaensis, and the top limit is defined just below the first appearance of $G$. plesiotumida. G. merotumida appears in the zone just above the base.

\section{Globorotalia plesiotumida Zone (N17)}

The base of the zone coincides with the first appearance of G. plesiotumida, and the top is placed just below the first evolutionary appearance of $G$. tumida.

Cores 558A-16 and 558A-15 are assigned to either the middle of uppermost N16 or lowest N17. Cores 558A-14 and 558A-13 are assigned to N17.

\section{Miocene/Pliocene}

\section{Globorotalia tumida-Sphaeroidinella subdehiscens paenedehiscens Zone (N18)}

This zone is defined at the base by the appearance of $G$. tumida, and the top is defined just below the first evolutionary appearance of Sphaeroidinella dehiscens. Core 558A-12 is assigned to the lower part of Zone N18 and Core 558A-11 to the upper part of the interval.

Typical keeled sinestral Globorotalia margaritae were first observed in Core 558A-12.

\section{Pliocene}

\section{Sphaeroidinella dehiscens-Globoquadrina altispira Zone (N19)}

The base of Zone N19 is marked by the first evolutionary appearance of $S$. dehiscens from its immediate ancestor Sphaeroidinellopsis subdehiscens paenedehiscens. The top is the horizon immediately below the first evolutionary appearance of Globorotalia acostaensis pseudopima (Blow, 1969).

Cores 558A-10 and 558A-9 are assigned to this interval. The last occurrence of Globigerina nepenthes was noted in Core 558A-10 and Globorotalia margaritae last appears in Core 558A-9.

\section{Globorotalia tosaensis tenuitheca Zone (N21)}

The base of the zone is placed at the horizon of the first evolutionary appearance of $G$. tosaensis tenuitheca and the top is placed immediately below the first appearance of $G$. truncatulinoides (Blow, 1969).

The interval from Core 558A-8 through Section 558A3-5 is assigned to this zone. The fauna is diverse and is characterized by $G$. tosaensis, $G$. crassaformis, G. prae- hirsuta, G. miocenica, G. pertenuis, Sphaeroidinella dehiscens, Globigerinoides conglobatus, and G. sacculifer.

\section{Pleistocene}

\section{Globorotalia truncatulinoides Zone (N22)}

The base of this zone is placed at the first appearance of $G$. truncatulinoides, which evolved from $G$. tosaensis. The zone is recognized and differentiated from the older N21 Zone by the angular and carinate G. truncatulinoides, even though the more rounded, nonkeeled $G$. tosaensis may persist into the zone.

Sections 558A-3-1, 558A-3-2, 558A-3-3, and 558A-3-4 contain specimens of the intermediate forms of the $G$. tosaensis-G. truncatulinoides sequence and are representative of this transitional zone close to the Pliocene/ Pleistocene boundary.

Cores 558A-2 and 558A-1 are late Pleistocene upper $\mathrm{N} 22$ and contain a well-preserved modern fauna with abundant Globorotalia truncatulinoides and $G$. inflata; and G. scitula, Globigerina bulloides, Globigerinoides ruber, G. obliquus, Neogloboquadrina pachyderma, $N$. dutertrei, Sphaeroidinella dehiscens. and Orbulina. Benthic foraminifers, ostracodes, and abundant diverse radiolarians are well preserved.

\section{SUMMARY}

At Site 558 (Holes 558 and 558A), a nearly complete and continuous sequence of lower Oligocene through Pleistocene sediments was recovered. At Site 563, a section of lower Oligocene to upper middle Miocene very similar in both fauna and lithology to Hole 558 was retrieved. This stratigraphic succession is an excellent reference section and the most complete succession for this part of the Atlantic.

Figure 5 is a chart showing the correlation of the foraminiferal zones encountered on Leg 82 (Holes 558, $558 \mathrm{~A}$, and 563), together with Hole 334 drilled on Leg 37. The section of lower-upper Miocene retrieved in Hole 334 approximates the time intervals missing from sections cored on Leg 82 . Therefore, we have a more complete sedimentary section than has previously been recovered from the Cenozoic of the Mid-Atlantic between $20-40^{\circ} \mathrm{N}$ latitude.

Preservation is good except for lower Oligocene faunas immediately overlying the basalt, which show destruction because of dolomite crystallization and fragmentation and/or dissolution in the middle and upper Miocene that may have been climatically induced.

Bolboforma, a Miocene algae (?), is present at both sites at approximately the same horizon, suggesting that it may be a useful marker.

\section{REFERENCES}

Becker, R. C., 1982. Oligocene foraminiferal zonation of a well in the Main Pass Area (Gulf of Mexico). [M. A. thesis] Washington University, St. Louis, Mo.

Beckmann, J. P., Bolli, H. M., Perch-Nielson, K., Proto Decima, F., Saunders, J. B., and Toumarkine, M., 1981. Major calcareous nannofossil and foraminiferal events between the middle Eocene and early Miocene. Palaeogeogr., Palaeoclimatol., Palaeoecol., 36(3/4): 155-190. 
Berggren, W. A., 1972. Cenozoic biostratigraphy and paleobiogeography of the North Atlantic. In Laughton, A. S., Berggren, W. A., et al. Init. Repts. DSDP, 12: Washington (U.S. Govt. Printing Office), 965-1001.

1978. Recent advances in Cenozoic planktonic foraminiferal biostratigraphy, biochronology, and biogeography: Atlantic Ocean. Micropaleontology, 24:337-370.

Berggren, W. A., and Amdurer, M., 1973. Late Paleogene (Oligocene) and Neogene planktonic foraminiferal biostratigraphy of the Atlantic Ocean (Lat. $30 \mathrm{~N}$ to Lat. $30 \mathrm{~S}$ ). Rev. Ital. Paleontol. Strat. 79:337-391.

Berggren, W. A., and Van Couvering, J. A., 1974. The late Neogene biostratigraphy, geochronology and paleoclimatology and the last 15 million years in marine and continental sequences. Palaeogeogr., Palaeoclimatol. Palaeoecol. 16(1/2):1-216.

1978. Biochronology. In Cohee, G. V., Glaessner, M, F., and Hedberg, H. D. (Eds.), The Geologic Time Scale: Tulsa, Oklahoma (Am. Assoc. Pet. Geol.), Studies in Geology, 6:39-55.

Blow, W. H., 1969. Late middle Eocene to recent planktonic foraminiferal biostratigraphy. In Brönnimann, P., and Renz, H. H., (Eds.), Proc. First Int. Conf. Plank. Microfossils: Leiden (E. J. Brill), 1: 199-422.

1970. Deep Sea Drilling Project, Leg 2, Foraminifera from selected samples. In Peterson, M. N. A., Edgar, N. T., et al., Init. Repts. DSDP, 2: Washington (U.S. Govt. Printing Office), 357-365. Brill).

1979. The Cainozoic Foraminifera, 3 vol., Leiden, (E. J.

Bolli, H. H., 1957. Planktonic foraminifera from the Oligocene-Miocene Cipero and Lengua Formations of Trinidad, B. W. I. U.S. Nat. Mus. Bull., 215:97-123.

1966. Zonation of Cretaceous to Pliocene marine sediments based on planktonic foraminifera. Bol. Inf. Asoc. Venez. Geol. Min. Pet., 9:3-32.

Caralp, M., Valenton, S., and Vigneaux, M., 1965. Les Foraminiferes pelagiques du tertiare terminal sub-aquitain. C. R. Hebd. Seances Acad. Sci., 261(17):3431-3434.

Hardenbol, J., and Berggren, W. A., 1978. A new Paleogene numerical time scale. In Cohee, G. V., Glaessner, M. F., and Hedberg, H. D. (Eds.), The Geologic Time Scale: Tulsa, Oklahoma (Am. Assoc. Pet. Geol, Studies in Geology, 6:213-234.

Jenkins, D. G., 1960. Planktonic foraminifera from the Lake Entrance oil shaft, Victoria, Australia. Micropaleontology, 6:345-371. ,1965. The origin of the species Globigerinoides trilobus (Reuss) in New Zealand. Contrib. Cushman Found. Foraminiferal Res. 16 (3):116-120.

1971. New Zealand Conozoic planktonic foraminifera. $N$. Z. Geol. Surv. Paleontol. Bull. 42:1-278.

Keller, G., 1980. Early to middle Miocene planktonic foraminiferal datum levels of the equatorial and subtropical Pacific. Micropaleontology, 26(4):372-391.

1981a. Planktonic foraminiferal faunas of the equatorial Pacific suggest early Miocene origin of the present oceanic circulation. Mar. Micropaleontol., 6:269-295.

,1981b. Miocene biochronology and paleoceanography of the North Pacific Mar. Micropaleontol., 6(5/6) (Spec. Is., Cenozoic Paleoceanogr.):535-551.

Lamb, J. L., and Stainforth, R. M., 1976. Unreliability of Globigerinoides datum. Am. Assoc. Pet. Geol. Bull., 60(9):1564-1569.

Miles, G. A., 1977. Planktonic Foraminifera from Leg 37 of the Deep Sea Drilling Project. In Aumento, F., Melson, W. G., et al., Init. Repts. DSDP, 37: Washington (U.S. Govt. Printing Office), 929-961.

Poore, R. Z., 1978. Oligocene through Quaternary planktonic foraminiferal biostratigraphy of the North Atlantic: DSDP Leg 49. In Luyendyk, B. P., Cann, J. R., et al., Init. Repts. DSDP, 49: Washington (U.S. Govt. Printing Office), 447-517.

Postuma, J. A., 1971. Manual of Planktonic Foraminifera: Amsterdam (Elsevier).

Salvatorini, G., and Cita, M. B., 1979. Miocene foraminiferal stratigraphy, DSDP Site 397 (Cape Bojador, North Atlantic). In von Rad, U., Ryan, W. B. F., et al., Init. Repts. DSDP, 47, Pt. 1: Washington (U.S. Govt. Printing Office), 317-373.

Srinivasen, M. S., and Kennett, J. P., 1981. Neogene planktonic foraminiferal biostratigraphy and evolution: Equatorial to Subantarctic, South Pacific. Mar. Micropaleontol. 6(5/6):499-533.
1983. The Oligocene-Miocene boundary in the South Pacific. Geol. Soc. Am. Bull., 94(6):798-812.

Stainforth, R. M., and Lamb, J. L., 1981. An evaluation of planktonic foraminiferal zonation of the Oligocene. Univ. Kans. Paleontol. Contrib., Paper 104.

Stainforth, R, M., Lamb, J. L., Luterbacher, H., Beard, J. H., and Jeffords, R. M., 1975. Cenozoic planktonic foraminiferal zonation and characteristics of index forms. Univ. Kans. Paleontol. Contrib., Paper 62.

Date of Initial Receipt: 21 April 1983

Date of Acceptance: 19 January 1984

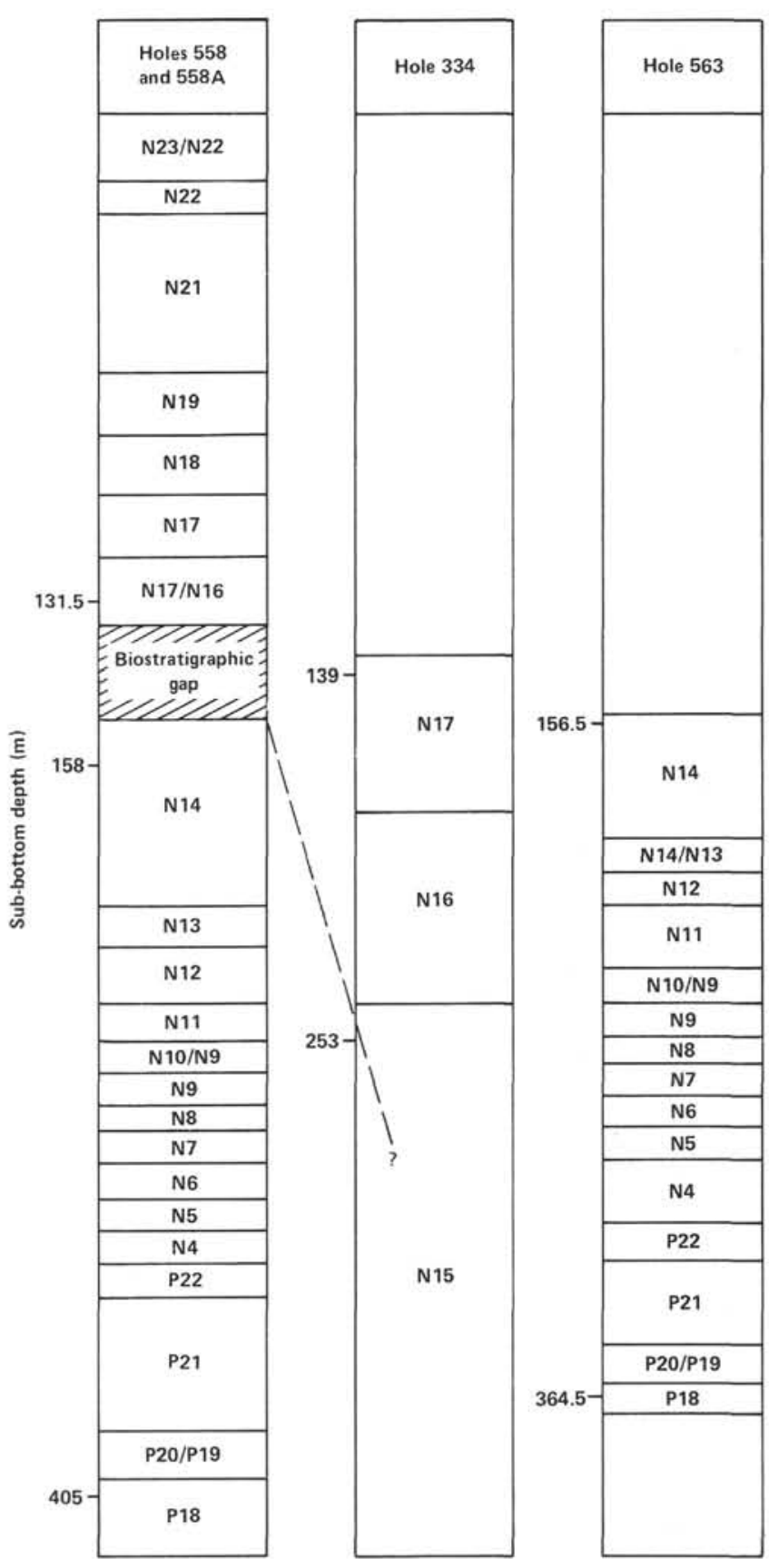

Figure 5. Correlation of the foraminiferal zones encountered on Leg 82 , Holes 558, 558A, and 563, with Hole 334 drilled on Leg 37 (Aumento, Melson, et al.). The section of early-late Miocene retrieved in Hole 334 approximates the time intervals missing from sections cored on Leg 82. 
APPENDIX A

Foraminifers from Site 558, Holes 558A and 558

\begin{tabular}{cccccc}
\hline $\begin{array}{c}\text { Core-Section } \\
\text { (interval in } \mathrm{cm})\end{array}$ & $\begin{array}{c}\text { Depth below } \\
\text { seafloor }(\mathrm{m})\end{array}$ & $\begin{array}{c}\text { Meters } \\
\text { recovered }\end{array}$ & Age & Ma & $\begin{array}{c}\text { Planktonic } \\
\text { zone }\end{array}$ \\
\hline
\end{tabular}

Hole 558A

1-1, 45-46

1, CC

2-1, 62-64

$2-2,62-64$

$2-3,62-64$

$2-4,62-64$
$2-5,62-64$

$2-6,62-64$

2, CC

3-1, 62-64

$3-2,62-64$

3-3, 62-64

$3-4,66-68$

$3-5,62-64$
$3-6,62-64$

3, CC

4-1, 62-64

4-2, 62-64

$4-3,62-64$

$4-5,62-64$

$4-5,62-64$

4-6, 62-64

5-1, 62-64

5-6, 62-64

5, CC

6-2, 70-73

6-3, 70-73

$6-4,70-73$

6-5, 70-73

$6, \mathrm{CC}$

6, CC

7-2, 90-93

$7-3$, 90-93

$7-4,90-93$
$7-5,90-93$

$7, \mathrm{CC}$

8-1, 90-93

8-2, 90-93

$8-3,90-93$

$8-4,90-93$

$8-5,90-$

$8, \mathrm{CC}$

$9-1,128-129$
$9-2,70-71$

9-3, 70-71

9, CC

$10-1,62,64$

$10-2,62-64$

$10, \mathrm{CC}$

$11-1,62-64$

$11-2,62-64$

$11-3,62-64$

$11-4,62-64$

$11-5,62-64$
$11-7,22-24$

I1, CC

$12-1,62-64$

12-2, 62-64

$12-3,62-64$

$12-4,62-64$

$12-5,62-64$
$12-6,24-26$

12 , CC

$13-1,62-64$

$13-2,62-64$

13-3, 62-64

$3-4,62-64$

13-5, 62-64

13, CC

14-1, 87-89

14-2, 62-64

$14-3,62-64$

$14-4,62-64$

$14-5,62-64$

$14-7,42-44$

14, CC

15-1, 62-64

$15-2,62-64$

$15-3,62-64$

$15-4,62-64$

15-6, 22-24

$15, \mathrm{CC}$

$16-1,62-64$

$16-3,62-64$

\begin{tabular}{|c|c|c|c|c|}
\hline $\begin{array}{l}0.0 \\
0.50\end{array}$ & 0.47 & $\begin{array}{l}\text { Pleistocene } \\
\text { (late) } \\
\text { Pleistocene } \\
\text { (late) }\end{array}$ & & $\begin{array}{l}\mathrm{N} 23 / \mathrm{N} 22 \\
\mathrm{~N} 23 / \mathrm{N} 22\end{array}$ \\
\hline 10.0 & 9.36 & $\begin{array}{l}\text { Pleistocene } \\
\text { (early) }\end{array}$ & & $\mathrm{N} 22$ \\
\hline 19.50 & 9.51 & $\begin{array}{l}\begin{array}{l}\text { Pliocene } \\
\text { (late) }\end{array} \\
\text { Pliocene } \\
\text { (late) }\end{array}$ & & N21 \\
\hline 29.00 & 9.32 & $\begin{array}{l}\text { Pliocene } \\
\text { (late) }\end{array}$ & & $\mathrm{N} 21$ \\
\hline 38.50 & 9.11 & $\begin{array}{l}\text { Pliocene } \\
\text { (late) }\end{array}$ & & $\mathrm{N} 21$ \\
\hline
\end{tabular}

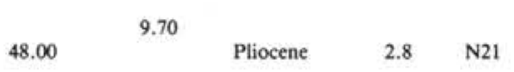

$\begin{array}{llll}57.50 & 8.22 & \text { Pliocene } & \text { N21 }\end{array}$

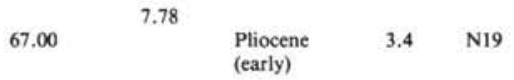

$\begin{array}{llll}74.00 & 4.76 & \text { N1iocene }\end{array}$

$\begin{array}{lllll}77.00 & 3.24 & & & \\ & & \text { Pliocene } & 5 \pm \quad \mathrm{N}\end{array}$

Miocene

86.50 $9.63 \quad \begin{aligned} & \text { Miocene } \\ & \text { (late) }\end{aligned} \quad$ N18

96.00 $8.47 \quad \begin{aligned} & \text { Miocene } \\ & \text { (late) }\end{aligned}$

103.00 $\quad 6.98 \quad \begin{aligned} & \text { Miocene } \\ & \text { (late) }\end{aligned}$

9.65

Miocene

(late)

8.11

122.00

Appendix A. (Continued).

\begin{tabular}{cccccc}
\hline $\begin{array}{c}\text { Core-Section } \\
\text { (interval in } \mathrm{cm})\end{array}$ & $\begin{array}{c}\text { Depth below } \\
\text { seafloor }(\mathrm{m})\end{array}$ & $\begin{array}{c}\text { Meters } \\
\text { recovered }\end{array}$ & Age & Ma & $\begin{array}{c}\text { Planktonic } \\
\text { zone }\end{array}$ \\
\hline
\end{tabular}

Hole 558A (Cont.)

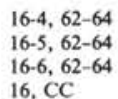

8.78

Hole 558

1-1, 37-40

$1-2,37-40$

$1-3,37-40$

$1-4,37-40$

$-5,37-40$
$1-6,37-40$

$1-6,37-40$

1.7, $\mathrm{CC}$

2-1, 110-113

$2-2,110-113$

$2-3,110-113$

$2-4,110-113$

$2-5,110-113$

$2, \mathrm{CC}$

3-1, 61-64

3-2, 61-64

$3-2,61-64$
$3-3,61-64$

$3-4,61-64$

$3-5,61-64$

3-6, 61-64

$3, \mathrm{CC}$

$4-1,61-64$
$4-2,61-64$

$4-2,61-64$
$4-3,61-64$

$4-4,61-64$

$4-5,61-64$

4-6, 61-64

$4, \mathrm{CC}$

5-1, 61-64

5-2, 61-64

S-3, 61-64

$5-4,61-64$

5-5, 61-64

$5-6,62-64$

$5, \mathrm{CC}$

6-1, 61-64

$6-2,61-64$

6-3, 61-64

6-4, 61-64

6-5, 61-64

6-6, 61-64

$6, \mathrm{CC}$

7-1, 32-35

$7, \mathrm{CC}$

8-1, 62-65

$8-2,62-65$

$8-3,62-65$

8-4, 62-65

$8, \mathrm{CC}$

9-2, 62-65

9, CC

10-1, 61-64

10, CC

$11-1,62-64$

$11, \mathrm{CC}$

$12-1,62-64$

$12-2,62-64$

12-3, 42-44

$12, \mathrm{CC}$

$13-1,62-64$

13-2, 62-64

$13-3,62-64$

$13-4,62-64$

$13-5,62-64$

$13, \mathrm{CC}$

$14-1,62-64$
$14-2,62-64$

$14-3,62-64$

$14-4,62-64$

$14-5,62-64$
$14-6,62-64$

$14-6,62$

15-1, 55-57

15-2, 62-64

$15-3,62-64$

158.00

$\begin{array}{lll}\begin{array}{l}\text { Miocene } \\ \text { (late- } \\ \text { middle) }\end{array} & 10.5 & \text { N14 } \\ & 12\end{array}$

167.50

9.15

Miocene

middle)

177.00

8.78

Miocene

(late-

N14

186.50

9.48

Miocene

(late-

N14

196.00

9.65

Miocene

(late-
middle)

205.50

9.40

Miocene

(late-

$\mathrm{N} 14 / \mathrm{N} 13$

middle)

215.00

9.05

224.50

0.89

Miocene

(middle)

Miocene

(middle)

$\frac{12}{13} \mathrm{~N} 13$

N12

5.65

243.50

253.00

253.00

262.50

Miocene

(middle)

Miocene

(middle)

Miocene

(middle)

Miocene

(middle)

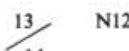

14. N11

15
15

$16 \quad \mathrm{~N} 9$

272.00

7.05

Miocene

(early-

middle)

281.50

9.00

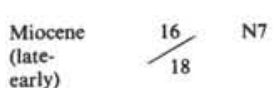

9.59

291.00

$\begin{array}{lcc}\begin{array}{l}\text { Miocene } \\ \text { (early) }\end{array} & 18.5 & \text { N6 }\end{array}$ 


\section{J. ECHOLS}

APPENDIX B

Appendix A. (Continued).

\begin{tabular}{|c|c|c|c|c|c|}
\hline $\begin{array}{l}\text { Core-Section } \\
\text { (interval in } \mathrm{cm} \text { ) }\end{array}$ & $\begin{array}{l}\text { Depth below } \\
\text { seafloor }(\mathrm{m})\end{array}$ & $\begin{array}{l}\text { Meters } \\
\text { recovered }\end{array}$ & Age & Ma & $\begin{array}{l}\text { Planktonic } \\
\text { zone }\end{array}$ \\
\hline \multicolumn{6}{|l|}{ Hole 558 (Cont.) } \\
\hline \multicolumn{6}{|l|}{$15-4,62-64$} \\
\hline \multicolumn{6}{|l|}{$15-5,80-82$} \\
\hline \multicolumn{6}{|l|}{$15-6,80-82$} \\
\hline \multirow{2}{*}{\multicolumn{6}{|c|}{$\begin{array}{l}16-1,62-64 \\
16-2,62-64\end{array}$}} \\
\hline & & & & $\frac{1}{20}$ & \\
\hline \multicolumn{6}{|l|}{$16-3,62-64$} \\
\hline \multicolumn{6}{|l|}{$16-4,62-64$} \\
\hline \multicolumn{6}{|l|}{$\begin{array}{l}16-5,62-64 \\
16-6,62-64\end{array}$} \\
\hline \multicolumn{6}{|l|}{$\begin{array}{l}16-6,62-64 \\
16 \text { CC }\end{array}$} \\
\hline \multirow{2}{*}{\multicolumn{6}{|c|}{$\begin{array}{l}17-1,58-60 \\
17-2,62-64\end{array}$}} \\
\hline \multirow{2}{*}{\multicolumn{6}{|c|}{$\begin{array}{l}17-2,62-64 \\
17-3,62-64\end{array}$}} \\
\hline & $17-4,62-64$ & & & & \\
\hline \multicolumn{6}{|l|}{$\begin{array}{l}17-4,62-64 \\
17-5,62-64\end{array}$} \\
\hline $17, \mathrm{CC}^{-04}$ & & 7.43 & & & \\
\hline $18-1,62-64$ & 319.50 & & Oligocene & $24+$ & P22 \\
\hline $18-2,62-64$ & & & (late) & $26+$ & \\
\hline $18-3,62-64$ & & & & & \\
\hline $18-4,62-64$ & & & & & \\
\hline $18-5,62-64$ & & & & & \\
\hline $\begin{array}{l}\text { 18, CC } \\
19-1,58-60\end{array}$ & 329.00 & 6.86 & Oligocene & & P21 (upper) \\
\hline $19-2,58-60$ & & & (late) & & T21 (apper) \\
\hline $19-3,58-60$ & & & & & \\
\hline $19-4,58-60$ & & & & & \\
\hline $19-5,58-60$ & & & & & \\
\hline 19, CC & & 7.60 & & & \\
\hline $20-1,62-64$ & 338.50 & & Oligocene & & P21 (upper) \\
\hline $20-2,62-64$ & & & (late) & & \\
\hline $20-3,62-64$ & & & & & \\
\hline $20-4,62-64$ & & & & & \\
\hline $\begin{array}{l}20-5,22-24 \\
20, \mathrm{CC}\end{array}$ & & 6.47 & & & \\
\hline $21-1,62-64$ & 348.00 & & Oligocene & 26 & P21 (upper) \\
\hline $21-2,62-64$ & & & (late) & 28 & \\
\hline $21-3,22-24$ & & 3.64 & & & \\
\hline $\begin{array}{l}21, C C \\
22-1,62-64\end{array}$ & 357.50 & & Oligocene & 28 & P21 (lower) \\
\hline $22-2,62-64$ & & & (early) & $100 / 3$ & \\
\hline $22-3,62-64$ & & & & & \\
\hline $22-4,62-64$ & & & & & \\
\hline $22, \mathrm{CC}$ & & 5.42 & & & \\
\hline $23-1,32-34$ & 367.00 & & Oligocene & & P21 (lower) \\
\hline $23-2,32-34$ & 307.00 & & Ongocene & & P21 (lower) \\
\hline $23-3,32-32$ & & & & & \\
\hline $23-4,32-34$ & & & & & \\
\hline $23-5,32-34$ & & & & & \\
\hline $23-6,32-34$ & & & & & \\
\hline 23, $\mathrm{CC}$ & & 9.36 & & & \\
\hline $24-1,42-45$ & 376.50 & & Oligocene & $30+$ & $\mathrm{P} 20 / \mathrm{P} 19$ \\
\hline $24-2,42-45$ & & & (early) & & \\
\hline $24-3,42-45$ & & & & & \\
\hline $24-4,42-45$ & & & & & \\
\hline $24, \mathrm{CC}$ & & 5.98 & & & \\
\hline $25-1,99-101$ & 386.00 & & Oligocene & $35+$ & P18 \\
\hline $25-2,99-101$ & & & (early) & & \\
\hline $25-3,99-101$ & & & & & \\
\hline $25-4,99-101$ & & & & & \\
\hline 25-5, 99-101 & & & & & \\
\hline $25-6,122-124$ & & & & & \\
\hline $25, \mathrm{CC}$ & & 8.97 & & & \\
\hline $26-1,18-20$ & 395.50 & & Oligocene & & P18 \\
\hline $26-2,18-20$ & & & (early) & & \\
\hline $26-3,18-20$ & & & & & \\
\hline $26-4,18-20$ & & & & & \\
\hline $26-5,18-20$ & & 6.94 & & & \\
\hline $\begin{array}{l}26, \mathrm{CC} \\
27.37-39\end{array}$ & 405.0 & & Oligocene & & \\
\hline $27-2,44-46$ & & & (early) & & \\
\hline $27, \mathrm{CC}$ & & 3.78 & & & \\
\hline
\end{tabular}

Foraminifers from Site 563, Hole 563

\begin{tabular}{|c|c|c|c|c|c|}
\hline $\begin{array}{l}\text { Core-Section } \\
\text { (interval in } \mathrm{cm} \text { ) }\end{array}$ & $\begin{array}{l}\text { Depth below } \\
\text { seafloor }(m)\end{array}$ & $\begin{array}{l}\text { Meters } \\
\text { recovered }\end{array}$ & Age & $\mathrm{Ma}$ & $\begin{array}{l}\text { Planktonic } \\
\text { zone }\end{array}$ \\
\hline $1-1,62-64$ & \multirow[t]{4}{*}{156.50} & & \multirow{4}{*}{$\begin{array}{l}\text { Miocene } \\
\text { (late- } \\
\text { middle) }\end{array}$} & \multirow{3}{*}{$\begin{array}{c}10.5 \\
+\end{array}$} & \multirow[t]{3}{*}{$\mathrm{N} 14$} \\
\hline $1-2,62-64$ & & & & & \\
\hline $1-3,62-64$ & & & & & \\
\hline $1, \mathrm{CC}$ & & 4.52 & & & $N 14$ \\
\hline $2-1,62-64$ & 166.00 & & Miocene & & $\mathrm{N} 14$ \\
\hline $\begin{array}{l}2-2,62-64 \\
2-3,62-64\end{array}$ & & & $\begin{array}{l}\text { (late- } \\
\text { middle) }\end{array}$ & & \\
\hline $2-5,62-64$ & & & & & \\
\hline $2-6,62-64$ & & & & & \\
\hline $2-7,22-24$ & & & & & \\
\hline 2, CC & & 9.62 & & & \\
\hline $3-1,62-64$ & 175.50 & & Miocene & & $\mathrm{N} 14$ \\
\hline $3-2,62-64$ & & & (late- & & \\
\hline $3-3,62-64$ & & & middle) & & \\
\hline $3-4,62-64$ & & & & & \\
\hline $\begin{array}{l}3-5,62-64 \\
3-6,62-64\end{array}$ & & & & & \\
\hline $3, \mathrm{CC}$ & & 9.02 & & & \\
\hline $4-1,62-64$ & 185.00 & & Miocene & & $\mathrm{N} 14$ \\
\hline $4-2,62-64$ & & & (late- & & \\
\hline $4-3,62-64$ & & & middle) & & \\
\hline $4-4,12-14$ & & & & & \\
\hline $4, \mathrm{CC}$ & & 5.01 & & & \\
\hline $\begin{array}{l}5-1,62-64 \\
5-4,62-64\end{array}$ & 194.50 & & $\begin{array}{l}\text { Miocene } \\
\text { (late- }\end{array}$ & & $\mathrm{N} 14 / \mathrm{N} 13$ \\
\hline $5-5,62-64$ & & & middle) & & \\
\hline $5-6,63-64$ & & & & & \\
\hline $5-7,19-21$ & & & & & \\
\hline $5, \mathrm{CC}$ & & 9.70 & & & \\
\hline $6-1,62-64$ & 204.00 & & Miocene & & $\mathrm{N} 12$ \\
\hline $\begin{array}{l}6-2,62-64 \\
6-3,62-64\end{array}$ & & & (middle) & & \\
\hline $\begin{array}{l}6-3,62-64 \\
6-4,62-64\end{array}$ & & & & & \\
\hline $6-5,62-64$ & & & & & \\
\hline $6-6,62-64$ & & & & & \\
\hline $6-7,22-24$ & & & & & \\
\hline $6, \mathrm{CC}$ & & 9.51 & & & \\
\hline $7-1,62-64$ & 213.50 & & Miocene & & N11 \\
\hline $\begin{array}{l}7-2,62-64 \\
7-3,62-64\end{array}$ & & & (middle) & & \\
\hline & & & & & \\
\hline $\begin{array}{l}7-4,62-64 \\
7-5,62-64\end{array}$ & & & & & \\
\hline $7-6,62-64$ & & & & & \\
\hline $7-7,22-24$ & & & & & \\
\hline $7, \mathrm{CC}$ & & 9.63 & & & \\
\hline $8-1,62-64$ & 223.00 & & Miocene & & NII \\
\hline $8-2,62-64$ & & & (middle) & & \\
\hline $8-3,62-64$ & & & & & \\
\hline $8-4,62-64$ & & & & & \\
\hline $8-5,62-64$ & & & & & \\
\hline & & 9.31 & & & \\
\hline $\begin{array}{l}8, \mathrm{CC} \\
9-1,50-52\end{array}$ & 232.50 & & Miocene & 15 & N10/N9 \\
\hline $9-2,50-52$ & & & (middle) & 16 & \\
\hline $9-3,50-52$ & & & & & \\
\hline $9-4,50-52$ & & & & & \\
\hline $9-5,50-52$ & & & & & \\
\hline $9-6,50-52$ & & & & & \\
\hline $9, \mathrm{CC}$ & & 9.58 & & & \\
\hline $10-1,45-47$ & 242.00 & & Miocene & & N9 \\
\hline $10-2,45-47$ & & & (middle) & & \\
\hline $10-3,45-47$ & & & & & \\
\hline $10-4,45-47$ & & & & & \\
\hline $10-5,45-47$ & & & & & \\
\hline $10-6,45-47$ & & 9.63 & & & \\
\hline $10, C C$ & & & & & \\
\hline $11-1,62-64$ & 251.00 & & Muocene & $16+$ & N8 \\
\hline $11-2,62-64$ & & & (early- & & \\
\hline $11-3,62-64$ & & & middle) & & \\
\hline $11-4,62-64$ & & & & & \\
\hline 11. CC & & 6.31 & & & \\
\hline $12-1,52-54$ & 261.50 & & Miocene & 16 & N7 \\
\hline $12-2,52-54$ & & & (late- & 18 & \\
\hline $12-3,52-54$ & & & early) & & \\
\hline $12-4,52-54$ & & & & & \\
\hline $12-5,52-54$ & & & & & \\
\hline $12-6,59-61$ & & & & & \\
\hline $12, \mathrm{CC}$ & & 9.50 & & & \\
\hline $13-1,129-131$ & 270.50 & & Miocene & 18.5 & N6 \\
\hline $13-2,62-64$ & & & (early) & + & \\
\hline $13-3,62-64$ & & & & & \\
\hline $13-4,62-64$ & & & & & \\
\hline $13-5,62-64$ & & & & & \\
\hline $13, C C$ & & 7.47 & & & \\
\hline $14-1,82-84$ & 280.00 & & Miocene & 19 & N5 \\
\hline $14-2,63-65$ & & & (early) & $\frac{1}{2}$ & \\
\hline $14-3,59-61$ & & & & & \\
\hline $14-4,10-12$ & & & & & \\
\hline $14-5,135-137$ & & & & & \\
\hline
\end{tabular}


LOWER OLIGOCENE THROUGH PLEISTOCENE PLANKTONIC FORAMINIFERS

Appendix B. (Continued).

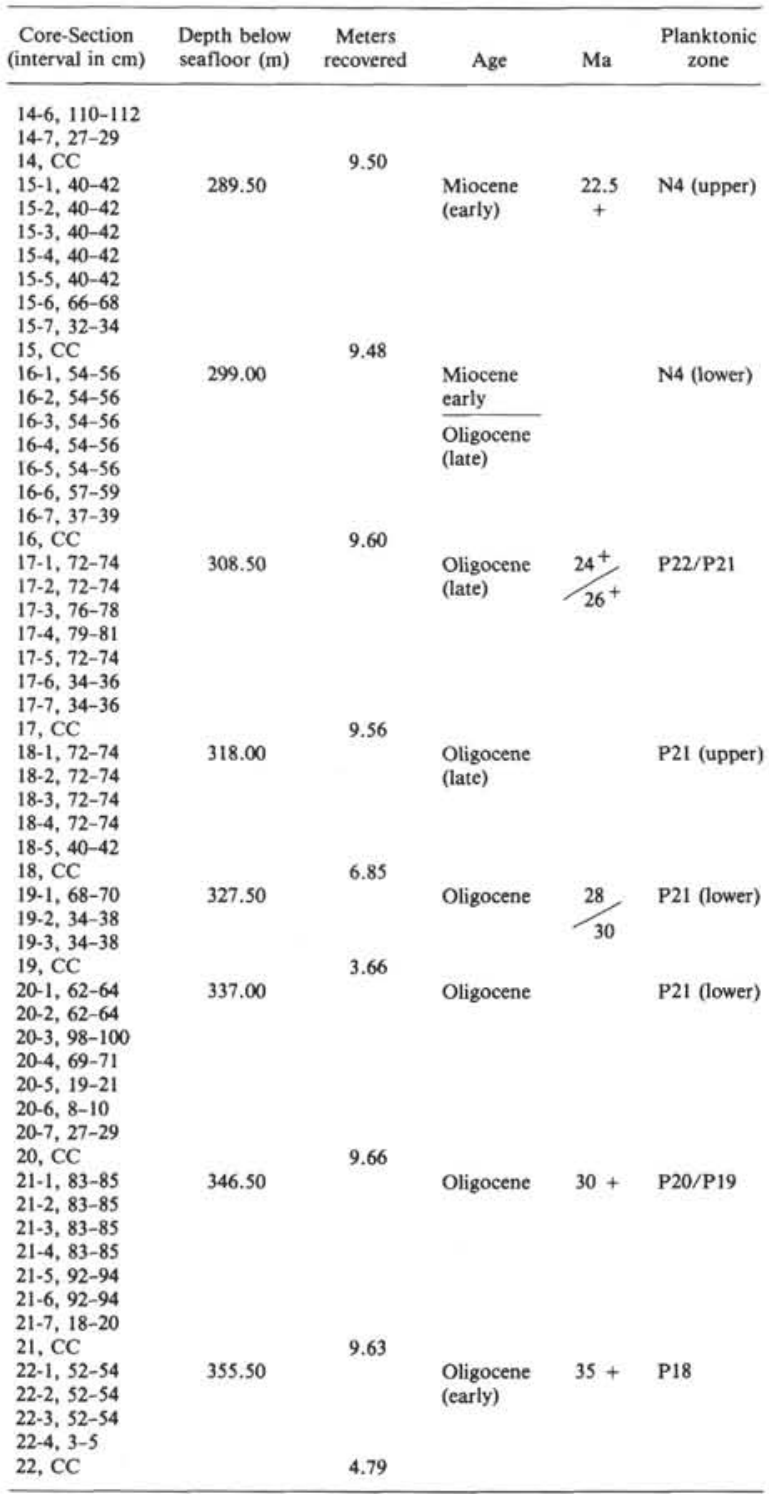



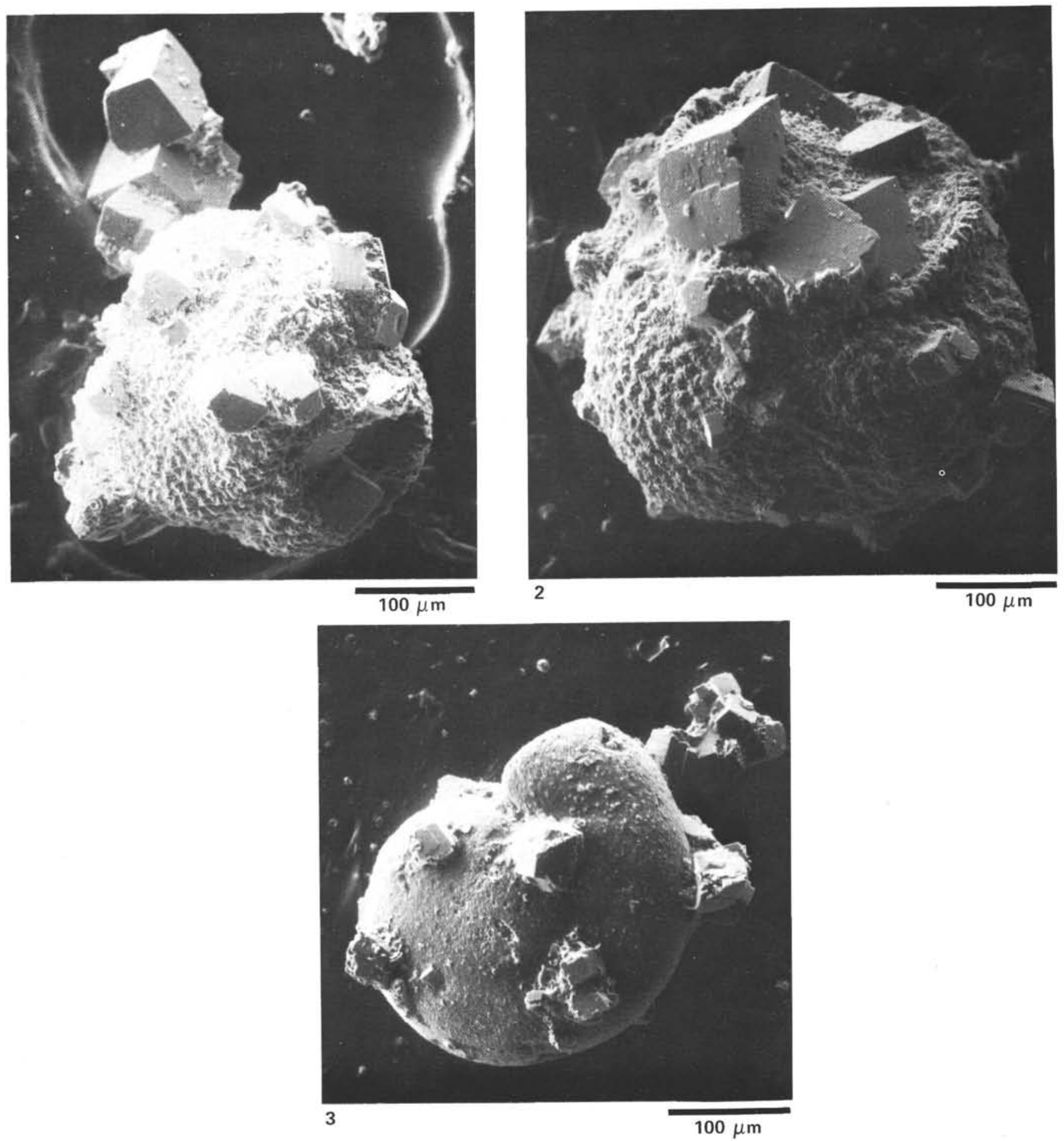

Plate 1. Oligocene foraminifers. 1, 2. Dolomite crystals growing in and on planktonic foraminifers. 3. Dolomite crystals growing on benthic foraminifer. 